\title{
Revalidation of Xysticus tuberosus Thorell, 1875 (Aranei: Thomisidae) with notes on the related species
}

\author{
Восстановление валидности Xysticus tuberosus Thorell, 1875 \\ (Aranei: Thomisidae) с заметками о бцизких видах
}

\author{
Yuri M. Marusik ${ }^{1,2}$, Kirill G. Mikhailov ${ }^{3}$ \\ Ю.М. Марусик ${ }^{1,2}$, К.Г. Михайлов ${ }^{3}$
}

\footnotetext{
${ }^{1}$ Institute for Biological Problems of the North, FEB RAS, Portovaya Str. 18, Magadan, 685000 Russia. E-mail: yurmar@mail.ru

${ }^{2}$ Department of Zoology \& Entomology, University of the Free State, Bloemfontein 9300, South Africa.

${ }^{3}$ Zoological Museum MGU, Bolshaya Nikitskaya Str., 2, Moscow 125009 Russia. E-mail: mikhailov2000@gmail.com

${ }^{1}$ Институт биологических проблем Севера ДВО РАН, ул. Портовая, 18, Магадан 685000 Россия.

3 Зоологический музей МГУ, ул. Большая Никитская, 2, Москва 125009 Россия.
}

KEY WORDS: Xysticus, Ozyptila, Caucasus, Southeastern Europe, Middle Asia, Central Asia, new combination.

КЛЮЧЕВЫЕ СЛОВА: Xysticus, Ozyptila, Кавказ, Юго-восточная Европа, Средняя Азия, Центральная Азия, новая комбинация.

ABSTRACT. Revision of the types of Xysticus lugubris Kroneberg, 1875 (now considered in Ozyptila) and $X$. tuberosus Thorell, 1875, thought to be a junior synonym of $X$. lugubris, and a study of recently collected material reveals that two names are not synonyms. A new combination, Ozyptila tuberosa comb.n., is suggested for $X$. tuberosus. Males of two species show clear differences in the shape of the embolus tip, although females are indistinguishable. Both species are illustrated and their copulatory organs are described. In addition, we illustrate Ozyptila inaequalis (Kulczyński, 1901), a species closely related to both $O$. lugubris and O. tuberosa. All these three species are not related to the types species of both Ozyptila and Xysticus and deserve the status of a separate genus.

How to cite this paper: Marusik Yu.M., Mikhailov K.G. 2021. Revalidation of Xysticus tuberosus Thorell, 1875 (Aranei: Thomisidae) with notes on the related species // Arthropoda Selecta. Vol.30. No.1. P.119124. doi: 10.15298/arthsel.30.1.11

РЕЗЮМЕ. Ревизия типовых экземпляров Xysticus lugubris Kroneberg, 1875 (ныне в роде Ozyptila) и $X$. tuberosus Thorell, 1875, который рассматривали как синоним предыдущего вида, и изучение недавно собранного материала показали, что эти два названия не являются синонимами. Для $X$. tuberosus предложена новая комбинация Ozyptila tuberosa comb.n. У самцов этих видов выявлены четкие различия в форме вершины эмболюса, тогда как самки неразличимы. Оба вида проиллюстрированы, даны описания их копулятивных органов. Дополнительно проиллюстрирован Ozyptila inaequalis (Kulczyński, 1901), вид, близкий к $O$. lugubris и O. tuberosa. Все эти три вида не род- ственны типовым видам родов Ozyptila и Xysticus и заслуживают выделения в отдельный род.

\section{Introduction}

Two important papers dealing with spiders from the southern regions of the Russian Empire were been published in the same year: Kroneberg [1875] and Thorell [1875], in which 45 and 64 new species, resoectively, were described. Therefore, it was hardly surprising that some of the species were found to be synonymous: Micaria modesta Kroneberg, 1875 and $M$. rossica Thorell, 1875, or Xysticus lugubris Kroneberg, 1875 (currently considered in Ozyptila Simon, 1864) and $X$. tuberosus Thorell, 1875 (see WSC [2021]).

In a study of thomisid spiders from Middle Asia, Marusik \& Logunov [1990] illustrated two types of the Ozyptila lugubris male palp. Specimens from the western part of Kazakhtsan showed the embolus bent near the tip, while material from the eastern regions had a straight embolus.

Recently, we have got the opportunity to revise the types of both species to find out that their males differ in embolus structure, while females have indistinguishable epigynes. The objective of this paper is to revalidate $X$. tuberosus, providing a new combination, to demonstrate the differences between the sibling species, as well as to briefly discuss their assignments.

\section{Material and methods}

Specimens were photographed using an Olympus Camedia E-520 camera attached to an Olympus SZX16 stereo microscope. Scanning electron micrographs were taken with a SEM JEOL JSM-5200 scanning electron microscope at 

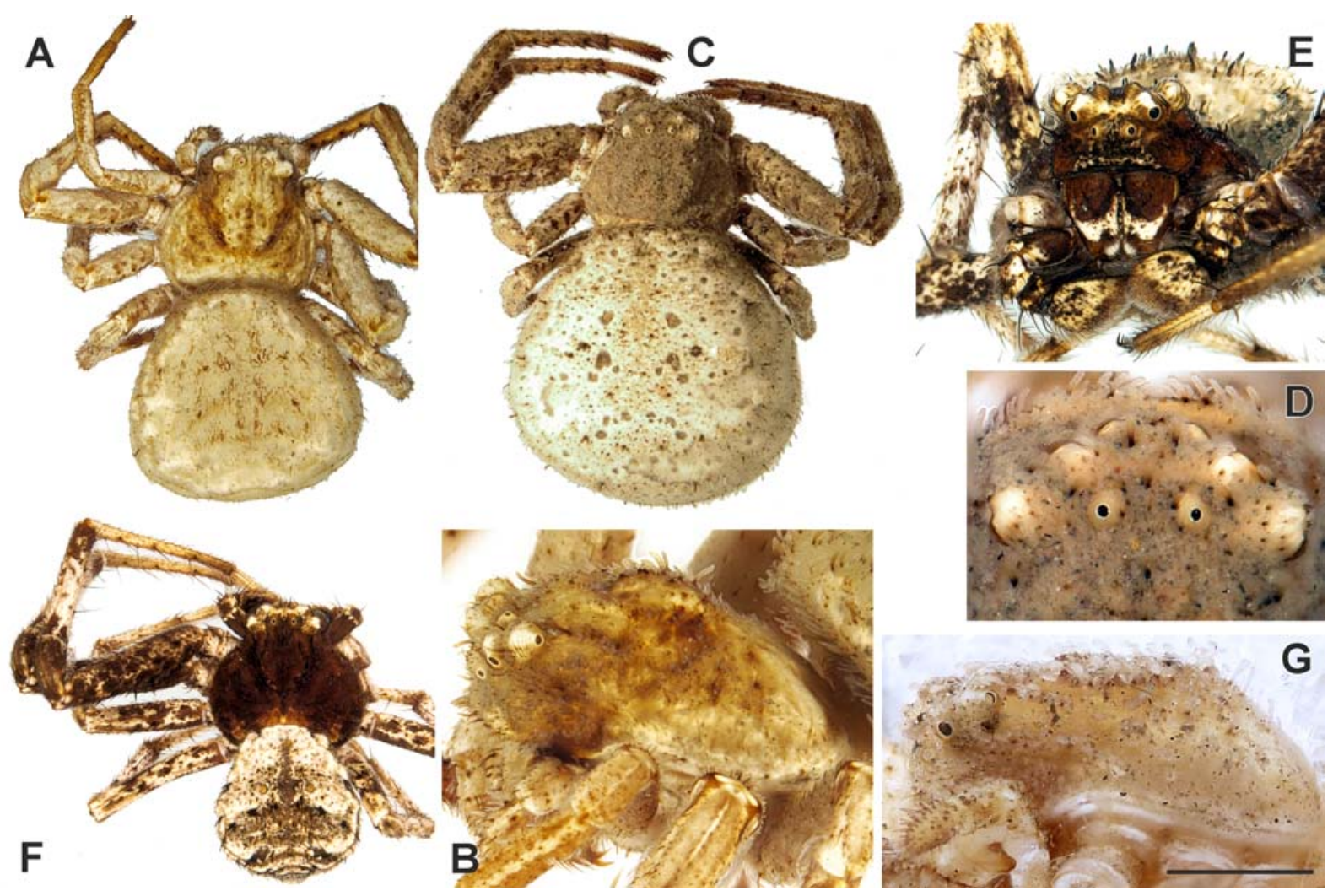

Fig. 1. Somatic characters of Ozyptila tuberosa (A-B - paralectotype $\odot, \mathrm{E}-\mathrm{F}-\bigcirc^{7}$, Zhanybek), O. lugubris (C-D, $\odot$, Almaty Area) and $O$. inaequalis $(\mathrm{G},+$, , China).

A, C - female habitus, dorsal; B, G - female prosoma, lateral; D - female carapace covered with sand grains; E-F - male habitus, frontal and dorsal. G - courtesy Yejie Lin \& Shuqiang Li.

Рис. 1. Соматические признаки Ozyptila tuberosa (A-B - паралектотип + , E-F - ○', Джаныбек), O. lugubris (C-D, 9 , Алматинская область) and $O$. inaequalis $(\mathrm{G}$, ,, , Китай).

A, C — внешний вид самки, дорсально; B, G - головогрудь самки, латерально; D — карапакс самки, покрытый песчинками; E-F — внешний вид самца, спереди и дорсально. G - любезно предоставлено Yejie Lin и Shuqiang Li.

the Zoological Museum of the University of Turku, Finland. Digital images were prepared using CombineZP image stacking software. Geographical names in Central Asia are spelled like in the labels. Depositories: ISEA - Institute for the Ecology and Systematics of Animals (Novosibirsk, Russia); NRS - Naturhistoriska Riksmuseet (Stockholm, Sweden); TNU - Taurian National University (Simferopol, Crimea); ZMMU - Zoological Museum of the Moscow State University (Moscow, Russia); ZMUH — Zoological Museum of University of Helsinki (Finland);

\section{Taxonomic survey}

Ozyptila lugubris (Kroneberg, 1875) Figs $1 \mathrm{C}-\mathrm{D}, 2 \mathrm{~F}, 3 \mathrm{~A}-\mathrm{C}$.

Xysticus lugubris Kroneberg, 1875: 35, pl. 3, f. 23a-f (О'P). Oxyptila lugubris: Simon, 1889: 381 (transferred to Ozyptila). Ozyptila lugubris: Utochkin, 1960: 49, f. 1-3 (O'

"Ozyptila" lugubris: Marusik, Logunov, 1990: 51, f. 52-53, 55-56 (O'P, figs 50-51, 54 refer to O. tuberosa).

Ozyptila lugubris: Mcheidze, 1997: 139, f. 216-217 (O' not + , $\sigma^{7}$ figure seems copy from Utochkin [1960]).

Non Oxyptila lugubris: Kulczyński, 1901: 316 (synonymized with $X$. tuberosus).
TYPES: Holotype $q$ with the museum number (ZMMU Ta1300 ) and label 'Туркестанская Учёная Экспедиция Императорского Общества Любителей Естествознания. [А.П.] Федченко. Самарканд' (Turkestan Scientific Expedition by the Imperator Society for Friends of Natural Sciences. A.P. Fedchenko. Samarkand). Other material from Sarepta mentioned in the text of the original description is absent from the ZMMU collection, possibly lost or handed over to NHRS, but not listed there as a "sp.n." (see below, under $O$. tuberosa).

OTHER MATERIAL EXAMINED: KAZAKHSTAN: $20^{7} 0^{7}$ (ISEA), Jambyl Area, environs of Furmanovka, 16.IX.1983 (Ch.K. Tarabaev, Yu.M. Marusik). $20^{7} \sigma^{7}$ (ISEA), Almaty Area, Balkhash Distr., N of Bakanas, 15.IX.1989 (S.I. Ibraev); 2 O $^{7} \sigma^{7}$ (ISEA), Panfilov Distr., $40 \mathrm{~km}$ SW of Panfilov Town, Kumkala Desert, 8.X.1989 (S.I. Ibraev, A.A. Zyuzin); $60^{7} 0^{7}, 6$ 우 (ISEA), Panfilov Distr., Kurnkala Clay Desert, 7.X.1989 (A.A. Zyuzin). TURKMENISTAN: $1 \sigma^{7}$ (ZMMU), environs of Ashgabad, Berzengi (375ำ $\left.58^{\circ} 21^{\prime} \mathrm{E}\right), 25 . X I .-1 . X I I .1980$ (G.T. Kuznetsov).

NOTE. The original species description is based on a female specimen from Samarkand, collected by A.P. Fedchenko [Kroneberg, 1875: 35] and additional specimens of both sexes from Sarepta, collected by A. Becker (his female specimens were also used as syntypes of $X$. tuberosus). It is noteworthy that the figure of the male palp of $X$. lugubris presented by Kroneberg agreed well with the specimens known from the central and eastern parts of Middle Asia, although he had male specimen from Saratov (that should 

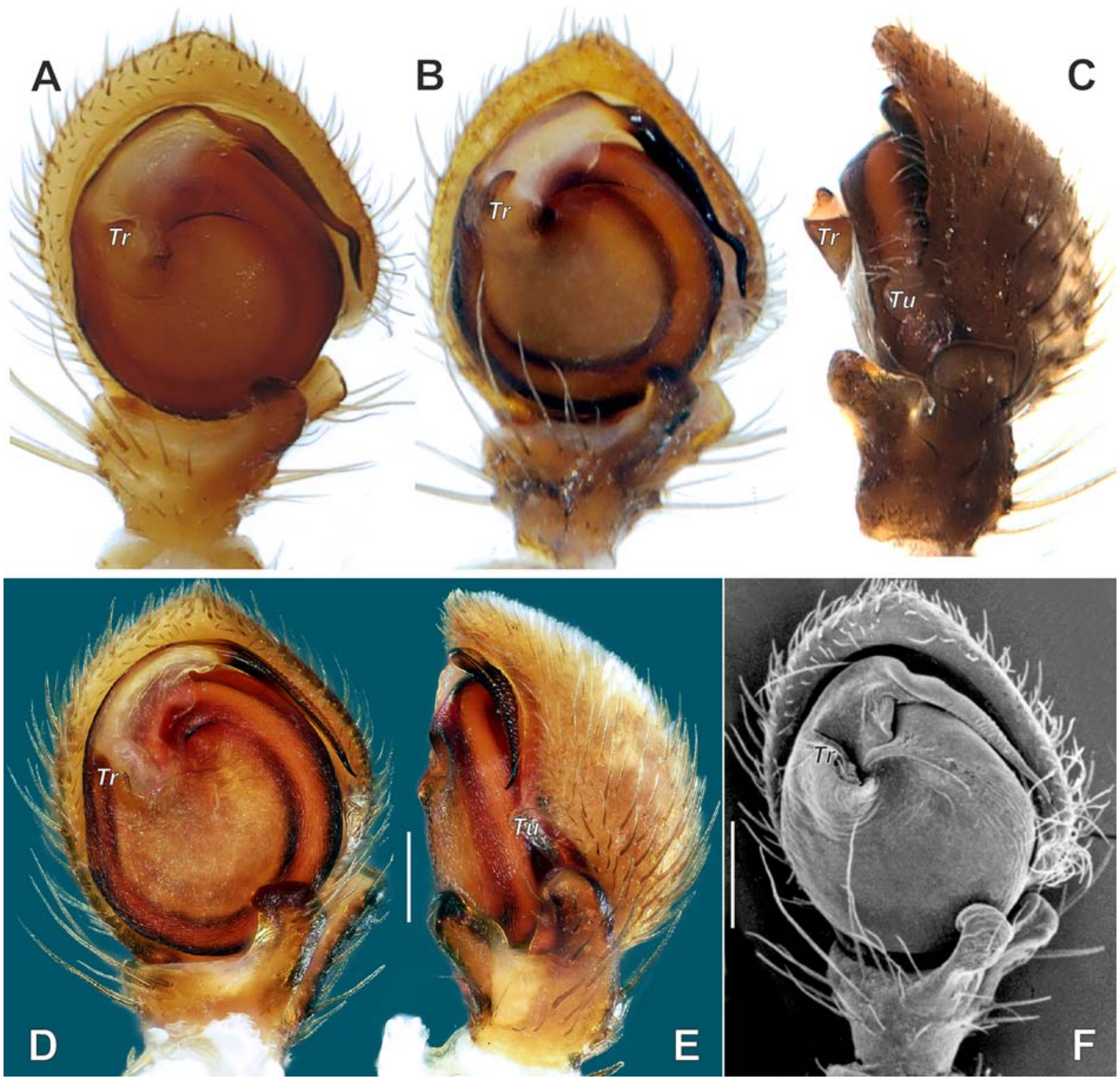
Area)

Fig. 2. Male palp of Ozyptila tuberosa (A - lectotype $\mathrm{O}^{7}$, B-C — from Zhanybek), O. inaequalis (D-E) and O. lugubris (F, Almaty

A-B, D, F - ventral; C, E - retrolateral. D-E - courtesy by Yejie Lin \& Shuqiang Li; F - courtesy by Pekka Lehtinen. Abbreviations: $T r$ - tegular ridge; $T u$ - tutaculum. Scale $=0.2 \mathrm{~mm}$ if indicated.

Pис. 2. Пальпа самца Ozyptila tuberosa (А - лектотип О7, В-C - из Джаныбека), O. inaequalis (D-E) и O. lugubris (F, Алматинская область).

A-B, D, F - вентрально; C, E - ретролатерально. D-E - любезно предоставлено Yejie Lin и Shuqiang Li; F - любезно предоставлено Pekka Lehtinen. Сокращения: $T r$ — тегулярный гребень; $T u$ - тутакулум. Масштаб 0,2 мм, если указан.

belongs to $X$. tuberosus). Most likely, Kroneberg overlooked the small turn of the embolus tip. Kulczyński [1901] provided no arguments to favour the species' transfer from Xysticus to Ozyptila. Most likely, the reason was the clavate numerous setae on the body and legs that are only known in Ozyptila.

DIAGNOSIS. The male of $O$. lugubris differs well from that of $O$. tuberosa by a straight embolus (vs. with a bent tip). Females have no distinct differences.

DESCRIPTION. For a somatic description, see Kroneberg [1875] and Marusik \& Logunov [1990]. Kroneberg
[1875] did not mention that the female abdomen was covered with sand grains.

Male palp with 2 tibial apophyses, both abrupt, not tapering; cymbium 1.2 times longer than wide, with a distinct and non-pointed tutaculum (Tt) in about a 4 o'clock position; tegulum lacking apophyses; tegular ridge located in a 10 o'clock position; pars pendula almost as wide as long (length/width ratio, 1.2); embolus originating in an almost 12 o'clock position (ca. 11:45), straight, gradually tapering, with fine transverse ridges. 

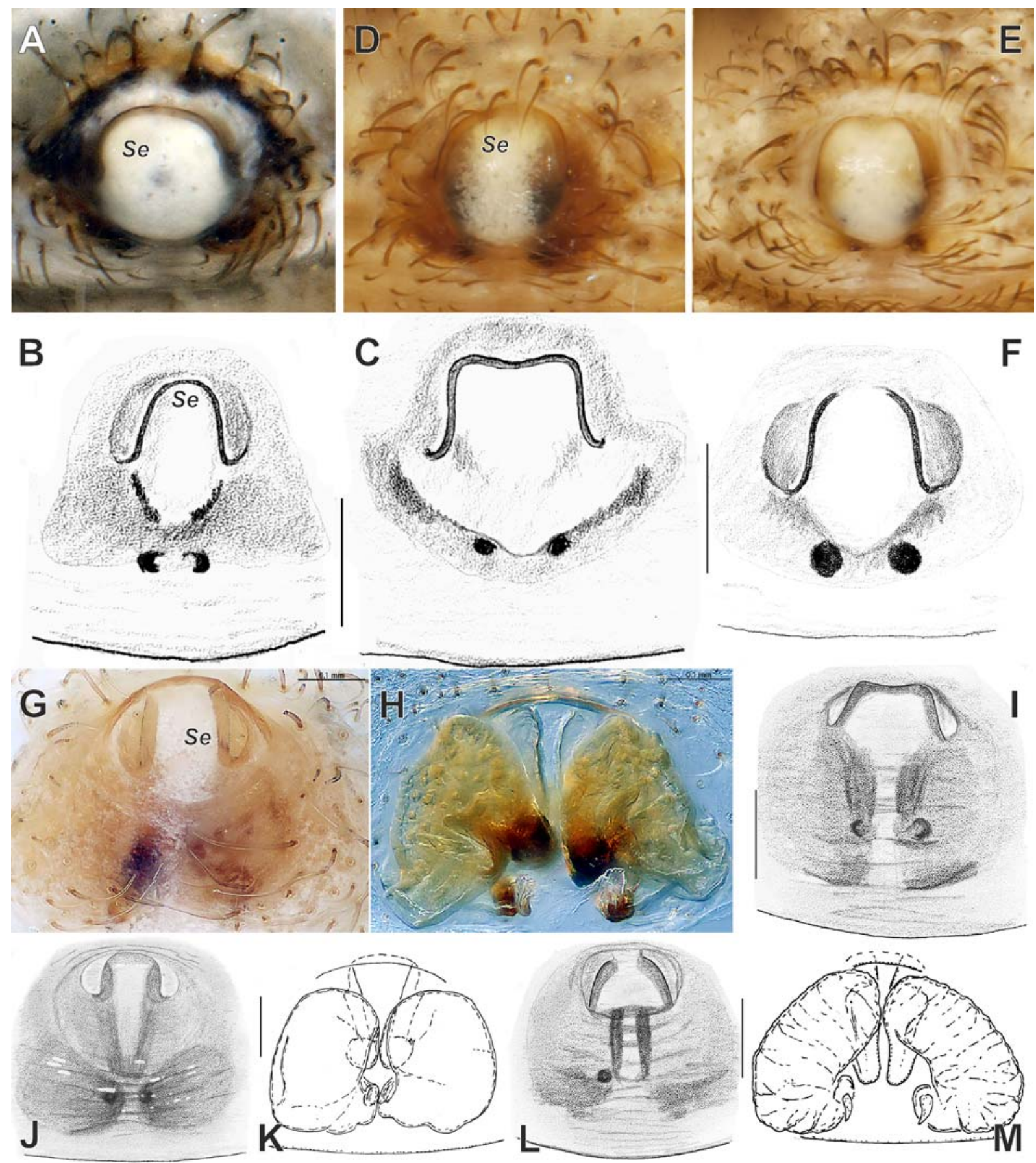

Fig. 3. Epigyne of Ozyptila lugubris (A-C), O. tuberosa (D-F) and O. inaequalis (G-M).

A-G, I, J, L - ventral; H, K, M - dorsal. A-C, I, M - from Almaty Area; D-E - paralectotypes; G-H - from Shanxi; F - from Ustyurt; J, K - from Chimkent Area. G-H - courtesy by Yejie Lin \& Shuqiang Li; A-C — after Marusik \& Logunov [1990]; I-M after Marusik \& Logunov [1995]. Abbreviation: $S e-$ septum. Scale $=0.2 \mathrm{~mm}$ if not otherwise indicated.

Рис. 3. Эпигина Ozyptila lugubris (A-C), O. tuberosa (D-F) и O. inaequalis (G-M).

A-G, I, J, L - вентрально; H, K, M - дорсально. А-C, I, M - из Алматинской области; D-E - паралектотипы; G-H - из Шаньси; F - с Устюрта; J, K - из Чимкентской области. G-H - любезно предоставлено Yejie Lin и Shuqiang Li; A-C - по Marusik \& Logunov [1990]; I-M — по Marusik \& Logunov [1995]. Сокращение: Se - септум. Масштаб 0,2 мм, если не указано иное. 
Epigyne with a septum raised over epigynal plate, rounded or abrupt anteriorly, slightly longer than wide; copulatory opening located on lateral sides of septum. Endogyne not studied.

DISTRIBUTION. This species seems to range from South Kazakhstan to northern Iran, in West Kazakhstan being is replaced with $O$. tuberosa. We checked the figures of the male recorded as $O$. lugubris from South Khorasan [Zamani et al., 2014] and found out that it had the same embolus as that from the Jambyl O. lugubris

\section{Ozyptila tuberosa (Thorell, 1875), comb.n., sp.revalid.}

Figs 1A-B, E-F, 2A-C, 3D-F.

\section{Xysticus tuberosus Thorell, 1875a: $88\left(\bigcirc^{7}+\right)$.}

Xysticus tuberosus: Thorell, 1875b: 128 ( $\left.\bigcirc^{\circ}+\right)$.

Oxyptila lugubris: Kulczyński, 1901: 316 (synonymized with $X$. tuberosus).

"Ozyptila" lugubris: Marusik, Logunov, 1990: 51, figs 50-51, 54 ( ${ }^{7}$, , figs $52-53,55-56$ refer to O. lugubris).

Ozyptila lugubris Demir, Seyyar, 2020: 228, f. 2A-B (O', misidentification).

TYPES: Lectotype $\sigma^{7}$ (designated herewith) and paralectotypes: 3 O+, 5 juveniles, labeled "Sarepta, Orianda, Sympheropo 1861, A. Becker" (Ent. etiketti 261), ZMUH. Paralectotypes: $1 \sigma^{\prime \prime}$ 2 우, labeled "Rossia merid." (A. v. Nordmann) in NHRS (Collectio Thorell 201/1144a); 1 q from Sarepta in NHRS (Collectio Thorell 201/1144b).

OTHER MATERIAL EXAMINED: CRIMEA: $2 \sigma^{\top} \sigma^{7}$ (TNU 1582/4 \& TNU-1582/4), Saki Distr., near Pribrezhnaya Railway Station $\left(45^{\circ} 09^{\prime} \mathrm{N} 33^{\circ} 30^{\prime} \mathrm{E}\right.$, wet salina and steppe, 27.08.-21.09.2000 (M.M. Kovblyuk). KAZAKHSTAN: WestKazakhstan Area, 4 ○' (ZMMU), Zhanybek Field Station, 2-20.IX.1982 (K.G. Mikhailov); $1 \bigcirc^{\top}, 1$ ( (ISEA), Mangyshlak Area, Yeraliyev Distr., Novyi Uzen' Town, 11.V.1989 (A.A. Raikhanov, S.I. Ibraev, A.A. Zyuzin); 9 O$^{\top}, 2$ 우 (ISEA), Yeraliyev Distr., Ust'yurt Plateau, Ust'yurt Nature Reserve, Baskargan Camp, 25.V.1989 (A.A. Raikhanov, S.I. Ibraev).

COMMENTS. Revision of the syntypes of Xysticus tuberosus and the material from Middle Asia identified as Ozyptila lugubris reveals that they are not conspecific, as it was erroneously treated by several authors [Kulczyński, 1901; Charitonov, 1932; Marusik, Logunov, 1990; Mikhailov, 2013; WSC, 2021]. Kulczyński [1901] synonymized the two names without comments. He indicated that he had studied the female from Saratov. Most probably, part of the O. lugubris original type series (from Sarepta; not labelled as "sp.n." = not indicated as types) which is kept in NHRS belongs to $O$. tuberosa.

DIAGNOSIS. Males of both sibling species, O. tubero$s a$ and $O$. lugubris, differ by the shapes of the embolus tip (bent, vs. straight, cf. Figs. 2A-B and 2F) and retroventral tibial apophysis. Females of these closely related species are indistinguishable.

DESCRIPTION. For a somatic description, see Thorell [1875a, b] and Marusik \& Logunov [1990].

Male palp with 2 tibial apophyses, both abrupt, nontapering; cymbium 1.2 times longer than wide, with a distinct and not pointed tutaculum $(T t)$ in about a 4 o'clock position; tegulum lacking apophyses; tegular ridge located in a 10 o'clock position; pars pendula almost as wide as long (length/width ratio, 1.2); embolus originating in a 12 o'clock position, straight, gradually tapering, bent in terminal $1 / 4$, covered with fine transverse ridges.

Epigyne with a septum raised over epigynal plate, rounded or abrupt anteriorly, slightly longer than wide; copulatory opening located on lateral sides of septum. Endogyne not studied.

DISTRIBUTION. The species seems to range from Crimea to the Ustyurt Plateau, and south to Turkey. Records of O. lugubris from the Caucasus (Dagestan, Georgia and Azerbaijan) [Otto, 2021] most probably refer to this species. Based on the figures of $O$. lugubris reported from Turkey [Demir, Seyyar, 2020], the samples undoubtedly belong to $O$. tuberosa. A single record from the environs of Varna, Bulgaria by Drensky [1936] cannot be verified in the lack of figures. If that was no misidentification, this record should belong to $O$. tuberosa.

\section{Discussion}

Both species considered in the paper, O. lugubris and $O$. tuberosa, are close to each other and differ from the type species of Xysticus C.L. Koch, 1835 (Aranea audax Schrank, 1803) or Ozyptila Simon, 1864 (Thomisus claveatus Walckenaer, 1837) by the shape of the copulatory organs. From all other genera of Coriarachninae, they differ by the female carapace and abdomen being covered with sand grains (a character unknown in other genera) and a raised cephalic part (vs. non-elevated). Establishing a new genus for $O$. lugubris was proposed by V.Ya. Fet (in litt.) back in the 1980's. Since the 1990's, some papers referred to the name "Ozyptila" for $O$. lugubris in quotation marks. There is one more species, $O$. inaequalis (Kulczyński, 1901), related to both $O$. tuberosa and $O$. lugubris. It was described based on the holotype female from "Khalgan" (= Kalgan, currently Zhangiiakou), China. It is known range from Eastern Kazakhstan [Marusik, Logunov, 1995] to Hebei [Li, Lin, 2016]. Since the male palp of this species has never been properly illustrated, we do so here and also provide the first digital photographs of the epigyne. The specimens illustrated in Figs 1G, 2D-E, 3G-M are from China, Shanxi, 4.IX.1980 (IZCAS-Ar.1812). The epigynes of specimens from the Almaty Area (Fig. 3I, M) agree well with those from China and have spaced fertilization ducts, while the female from Chimkent shows fertilization ducts touching each other (Fig. 3J-K). This may indicate that they belong to different species.

Acknowledgmenets. We thank Shuqiang Li and Yejie Lin (Beijing, China) for supplying us with figures of $O$. inaequalis, Mykola M. Kovblyuk (Simferopol) and Alexander V. Ponomarev (Rostov-on-Don) for information about the distribution records and material of $O$. tuberosa in Crimea and the northern Caucasus. Omid Mirshamsi (Mashhad, Iran), Seppo Koponen (Turku, Finland) and Torbjörn Kronestedt (Stockholm, Sweden) for the help in getting access to the syntype series of "Xysticus tuberosus". We also thanks Mikhail M. Omelko (Vladivostok, Russia) for reviewing our manuscript. The English of the final draft was kindly edited by Sergei Golovatch (Moscow). The work of the second author (KM) is supported by MSU Zoological Museum State Program. 


\section{References}

Demir H., Seyyar O. 2020. A new record of Ozyptila lugubris (Kroneberg, 1875) (Araneae: Thomisidae) from Turkey // Serket. Vol.17. No.3. P.227-229.

Charitonov D.E. 1932. [Katalog der russischen Spinnen]. Leningrad: AN SSSR Publ. 206 p. [In Russian and German]

Drensky P. 1936. Katalog der echten Spinnen (Araneae) der Balkanhalbinsel // Sbornik na Bolgarskata akademiya na naukite. Kniga 32. $223 \mathrm{~S}$

Kroneberg A.I. 1875. [A.P. Fedchenko. Voyage in Turkestan. Spiders. Araneae] // Izvestiya Obshchestva lyubitelei estestvoznaniya, antropologii i etnografii. Vol.19. No.3. P.I-IV, 1-55, 5 tabs [in Russian].

Kulczyński W. 1901. Arachnoidea // Horvath G. (Hrsg.). Zoologische Ergebnisse der dritten asiatischen Forschungsreise des Grafen Eugen Zichy. Budapest. Bd.2. S.311-369.

Li Shuqiang, Lin Yucheng. 2016. Species cataloque of China. Volume 2. Animalia. Invertebrates (I). Arachnida: Araneae. Beijing: Science Press. 567 p. [In Chinese]

Marusik Yu.M., Logunov D.V. 1990. The crab spiders of Middle Asia, USSR (Aranei, Thomisidae). 1. Descriptions and notes on distribution of some species // Korean Arachnology. Vol.6. No.1. P.31-62.

Marusik Yu.M., Logunov D.V. 1995. The crab spiders of Middle Asia (Aranei, Thomisidae), 2 // Beiträge zur Araneologie. Bd.4. P.133-175.

Mcheidze T.S. 1997. [Spiders of Georgia (systematics, ecology, zoogeographical review)] Tbilisi: Tbilisi State Univ. Press. 390 p. [In Georgian, with Russian summary]
Mikhailov K.G. 2013. Advances in the study of the spider (Aranei) fauna of Russia and adjacent regions: a 2011 update // Arthropoda Selecta. Vol.22. No.1. P.47-53.

Otto S. 2021. Caucasian Spiders. A faunistic database on the spiders of the Caucasus. Version 1.4. Internet: http://caucasusspiders.info/ Accessed on February 28, 2021

Thorell T. 1875a. Verzeichniss südrussischer Spinnen // Horae Societatis Entomologicae Rossicae. T.11. S.39-122.

Thorell T. 1875b. Descriptions of several European and North African spiders // Kongliga Svenska Vetenskaps-Akademiens Handlingar. Bd.13. H.5. P.1-204.

Utochkin A.S. 1960. [Materials to the fauna of spiders of the genus Oxyptila Sim. in USSR] // Uchenye Zapiski Permskogo Gosudarstvennogo Universiteta. Vol.13. P.47-61 [in Russian]

Simon E. 1889. Arachnidae transcaspicae ab ill. Dr. G. Radde, Dr. A. Walter et A. Conchin inventae (annis 1886-1887) // Verhandlungen der Kaiserlich-Königlichen Zoologisch-Botanischen Gesellschaft in Wien. Bd.39. P.373-386.

WSC. 2021. World Spider Catalog. Version 22.0. Natural History Museum Bern, online at http://wsc.nmbe.ch, accessed on February $28,2021$.

Zamani A., Nikmagham Z., Allahdadi M., Ghassemzadeh F., Mirshamsi O. 2014. New data on the spider fauna of Iran (Arachnida: Araneae) // Zoology in the Middle East. Vol.60. No.4. P.362-367

Responsible editor S. Koponen 